ISSN: 1110-5623 (Print) - 2090-0570 (Online)

\title{
EFFECT OF SPEARMINT (MENTHA SPICATA ) ON PRODUCTIVE AND PHYSIOLOGICAL PARAMETERS OF BROILER CHICKS
}

Aida A. Abu Isha1, A. E. Abd El-Hamid', H. M. Ziena ${ }^{2}$, and H. A. Ahmed ${ }^{3}$

${ }^{1}$ Dep. of Anim. and Poult. Prod., Fac. of Agric., Damanhour Uni. ${ }^{2}$ Dep. of Food and

Dairy Sci. \& Tech., Fac. of Agric., Damanhour Uni.. ${ }^{3}$ Dep. of Nut. and Veter. Clinic.

Nut., Fac. of Veter. Mede., Damanhour Uni..

Corresponding author: E- mail: Abd El-Hamid @ Agr. dmu. edu. Eg

Received: 26/07/2018 Accepted: 19/08/2018

\begin{abstract}
This study was conducted to determine the effect of spearmint (Mentha spicata) on productive and physiological performance of broiler chicks. One hundred and eighty day old unsexed (Arbor Acres) broiler chicks were used in this experiment. Birds were distributed randomly into four equal treatment groups, in three replication, 15 chicks each. The dietary treatments including T1(control diet), T2 with addition $0.5 \%$ spearmint, $\mathrm{T} 3$ with addition $1 \%$ spearmint and $\mathrm{T} 4$ with addition $2 \%$ spearmint. Feed and water were provided ad-libitum. Body weight, body weight gain, feed consumption and feed conversion ratio were weekly recorded. At the end of the experimental period (42 days of age), three birds were randomly chosen to determine both hematological and blood biochemical parameters and carcass traits. The results indicated that the addition of 0.5 and $1 \%$ spearmint did not significantly $(\mathrm{P}>0.05)$ affect final body weight, total gain compared with the control group, while the supplementation of different levels of spearmint to the diets of broiler chicks improved feed conversion ratio, also there was significant differences between the control group and the groups treated with different spearmint levels on feed consumption. The chickens fed diet supplemented with $2 \%$ spearmint had significantly lower body weight, total gain and feed consumption compared to the control group and the other treatments. There were an increase numerically in $\mathrm{Hb}$ concentration and red blood cell count in chickens fed diet supplemented with $2 \%$ Spearmint compared to the control group and the same group had lower significantly in the total cholesterol compared with the control group and the other groups. Chickens fed diet supplemented with 1\% Spearmint had significantly higher concentration of total plasma lipid. There were no significant differences in carcass traits between the control group and the groups supplemented with $0.25,0.5$, and $1 \%$ spearmint in chicken diet. There was a significantly higher superoxide dismutase (SOD) activity in group treated with $2 \%$ Spearmint. Meanwhile, the chicken supplemented with $1 \%$ Spearmint had higher significantly total antioxidant capacity (TAC) compared with the control group and the other treated groups.
\end{abstract}

Keywords: spearmint - productive - physiological - broiler 
Aida A. Abu Isha ${ }^{1}$ et al.

\section{INTRODUCTION}

Throughout the world, the use of antibiotics are considered as dietary growth promoter, today their use as growth promoters in animal nutrition has become undesirable due to the appearance of residues and resistant strains of bacteria; (Yoshimura et al., 2000) and Elamin et al., 2015. The phasing out of Antibiotic Growth Promoters (AGP) will affect the poultry and animal industry widely. To minimize the loss in growth, there is a need to find alternative to AGP. There are a number of non-therapeutic alternatives such as enzymes, inorganic acids, probiotics, prebiotics, herbs, immune stimulant and other management practices (Banerjee, 1998).

Herbs are an ancient source of medicine, flavoring, beverages, dyeing, fragrances and cosmetics uses that have attracted biotechnology, cosmetics, pharmaceutical and food industries. Mentha is a genus of widely distributed aromatic perennial herbs that grows in the temperate regions of Eurasia, Australia and South Africa. The mint species possesses both medicinal and commercial importance. The leaves, stems and flowers of Mentha species are used in various foods to offer aroma and flavor and is also used in herbal teas. It has also been used as a folk remedy for treatment of fevers, headaches, digestive disorders, bronchitis, ulcerative colitis, liver complaints etc. Spearmint (Mentha spicata) and Peppermint (Mentha piperita) are among the important members of the Lamiaceae family (Zaidi and Dahiya, 2015). Spearmint is an aromatic herbal plant used widely in cosmetic, confectionary, chewing gum, food, toothpaste, pharmaceutical industries and for essential oil productions. It is an important herb used fresh and dried for folk medicine such as stimulant and carminative. The essential oil is extracted from freshly harvested mint leaves or from dried leaves via distillation process. The essential oil obtained has been shown to possess antibacterial, antifungal, antiviral, insecticidal and antioxidant properties (Singh and Aggarwal, 2013). The essential oil contains significant amounts of limonene, dihydrocarvone, and 1,8- cineol (Hussain et al., 2010). The distinctive smell of spearmint oil is because of its most abundant compound carvone. Moreover, Al - kassie (2010) found that there is an important in performance traits (weekly body weight, feed conversion ratio and dressing percentage) for broiler chicks fed diet supplemented with $0.25,0.5,1$ and $1.5 \%$ peppermint compared with the control group and there was no significant effect was noticed on the addition of the peppermint to the diet on blood traits (Packed cell volume\%, Red blood cell count, Hemoglobin concentration\% and White blood cell count). This results in agreement with the observations made by Ocak et al. 2008, Cross et al. 2007 and Bampidis et al. 2005). The aim of this study to determine the effect of Mentha spicata leaves on physiological and productive performance in broiler chickens during the experimental period from 7 to 42 days of age.

\section{MATERIALS AND METHODS}

The present study was carried out at the Graduate Studies Institute and Environmental Research - Damanhour University. Throughout the period from 2015 to 2016. One hundred and eighty, one day old broiler chicks (Arbor Acres) were divided into four equal treatment groups. The dietary treatments including T1 (control diet), T2 with addition $0.5 \%$ 
Spearmint, T3 with addition 1\% Spearmint, T4 with addition 2\% Spearmint. During the experimental period (7-42 days) chicks were fed ad libitum starter diet from 7-24 days containing $23 \%$ crude protein, $3.39 \%$ crude fiber, $3.82 \%$ ether extract and 3000 $\mathrm{kcal} / \mathrm{kg}$ diet metabolizable energy and finisher diet from 25-42 days containing $21 \%$ crude protein, $3.25 \%$ crude fiber, $3.93 \%$ ether extract and $3050 \mathrm{kcal} / \mathrm{kg}$ diet metabolizable energy. All chickens were raised under similar environmental hygienic and managerial conditions. Feed and water was added ad libitum.

\section{Data collected:}

\section{Growth performance}

At the beginning and the end of experimental period, the birds were individually weighed to the nearest gram to calculate the changes in live body weight. Chicks were weighed in the early morning before receiving any food. Body weight gains was calculated by subtracting body weight at end of the period from the initial body weight at the beginning using individual record for each bird. Feed consumption (FC"g") was calculated by subtracting the amount of feed left from the feed supplied. Feed to gain ratio (FCR) was calculated in the form of units of feed intake required to produce one unit of live body weight gain.

\section{Hematological parameters}

At the end of the experimental period (42 days of age), a total of 12 blood samples (3 samples/treatment) were collected randomly from the wing vein in heparinized tubes to determine the hematological parameters, i.e. hemoglobin concentration $(\mathrm{Hb})$ according to (Tietz, 1982), hematocrite value (HT\%) (Wintrobe, 1965), red blood cell count (RBC`s) (Hawkeye and Dannett,
1989), white blood cell count (WBC`s)

(Hawkeye and Dannett, 1989) .

The mean cell volume (MCV), the mean cell hemoglobin $(\mathrm{MCH})$ and the mean cell hemoglobin concentration (MCHC) were calculated by the following equations:

MCV $\left(\operatorname{micron}^{3} /\right.$ red blood cell $)=$ Hematocrite $\times 10$

Number of Rbcs

$\mathrm{MCH} \quad(\mathrm{pg}) \quad=$

Hemoglobin concentration $(\mathrm{g} / \mathrm{dl}) \times 10$

Number of Rbcs

$\operatorname{MCHC}(\%)=\frac{\text { Hemoglobin }(\mathrm{g} / \mathbf{d l})}{\% \text { Hematocrit } \times \mathbf{1 0 0}}$

Meanwhile, a part of each sample was withheld to obtain serum. Plasma and serum were obtained by centrifugation of blood at 3,000 rpm for 20 minutes, and stored at $-20^{\circ} \mathrm{C}$ for later analysis.

\section{Blood biochemical constituents}

Serum total protein $(\mathrm{g} / 100 \mathrm{ml})$ was measured according to Doumas et al., (1981). Serum total albumin was determined according to Doumas et al. (1971) and serum total globulin was estimated by the subtracted serum total albumin from serum total protein. Total glucose was determined according to Hyvarinen and Nikkila, (1962). Serum total triglycerides (Bogen and Kaller, 1987) and total cholesterol (Allain et al., 1974). Total lipids were measured according to Chabrol and Channat, (1973).

\section{Carcass traits}

At the end of the experiment (42 days of age), three birds from each treatment were randomly chosen to determine carcass traits. Carcass, abdominal fat, intestine and internal organs (liver, gizzard, heart, proventriculus, pancreas) weights were recorded. Intestinal length was individually measured $(\mathrm{Cm})$. All percentages were calculated as relative to the live pre-slaughter weight. 
Aida A. Abu Isha ${ }^{1}$ et al.

\section{Antioxidant status}

The method of Koracevic et al., (2001) was used to determine the total antioxidant capacity (TAC) and the Superoxide dismutase (SOD) was determined by the method of Beauchamp and Fridovich, (1971).

\section{Statistical analysis}

The statistical analysis of the experimental data was computed using analysis of variance procedure described in the SAS (2002), mean differences were compared using the least significant difference (L.S.D.).

\section{RESULTS AND DISCUSSIONS}

Data in (Table 1) indicated that at 42 days of age, there was a significant difference between the treatment group that fed diets with $2 \%$ spearmint level and the other groups on final body weight and total body weight gain. Chickens fed diet supplemented with $2 \%$ spearmint (T4) had significantly lower body weight and total body weight gain compared with the control group and the other treatments. As the control group, it was decreasing by $0.081,0.087$ in final body weight and total body weight gain, respectively. Feed consumption decreased significantly $(\mathrm{P}<0.05)$ with increasing level of spearmint in the basal diet with the following ranking: birds fed diet with $2 \%$ spearmint had significantly the lowest feed consumption (2631g/chicks), followed by birds fed diet 1\% (2807 g/chicks), $0.5 \%$ (2942 g/chicks) while the highest feed consumption was obtained by birds fed the control diet (3016 $\mathrm{g} /$ chicks). There was significant effect of supplemented of spearmint levels $0.5,1$ and $2 \%$ compared with the control group on feed conversion ratio and the results showed improvement in FCR of chicks that fed on the diets supplemented with spearmint.
The higher body weight gain observed in broilers fed the peppermint diet may be related to the properties of menthol (Lovkova et al., 2001). Al-Kassie, (2010) found that the difference in body weight gain between the control and peppermint group was not reflected in the body weights of slaughter age. Such a case can firstly be explained by the fact that the old birds were better able to perform with finisher basal diet due to the fact that the nutrient requirements decrease with age (NRC, 1994). In addition, the development of the digestive tract and organs (Lilja, 1983).

Similarly, Amal (2012) reported that, addition of spearmint essential oils, to the diet increased significantly the feed intake of broiler chicks, also, Galib et al. (2010) stated that the broiler chicks fed on peppermint (Mentha piperita) powder consumed significantly more feed consumption compared to the control group.

On the other hand, Howida, (2009) and Bushra, (2011), found that diet at levels of $1,1.5,2 \%$ had no significant effect on feed intake and feed conversion ratio. This could be explained as some researchers reported that, the pharmacologically active substances (phenolic compounds and alkamides) that they supposed to enhance feed digestion and absorption by stimulating secretion of digestive enzymes lead to better feed utilization and assimilation, (Durrani et al., 2007, Jafari et al., 2011).

Mukhtar et al. (2013) stated that the improvement of FCR resulted from the increase in appetite due to the stimulation of salivary and gastric glands by spearmint oil (SPO), the decrease in pathogenic bacteria and better digestibility. 
There were no significant effect on Hemoglobin concentration ( $\mathrm{Hb})$, Red blood cell count (RBC), Hematocrit value (HT), Mean corpuscular volume (MCV), Mean corpuscular hemoglobin (MCH), and Mean corpuscular hemoglobin concentration (MCHC) (Table 2). However, there were increments numerically in $\mathrm{Hb}$ concentration and Red Blood cell count in chickens fed diet supplemented with $2 \%$ Spearmint compared with the control group. As the percentage of control group, it was increased by $5.63 \%$ and $6.48 \%$.

Al-Kassie, (2010) mentioned that the hematological parameter indicated no significant $(\mathrm{P}<0.05)$ between different treatments $(0,0.25,0.5,1$ and $1.5 \%$ peppermint "Mentha spicata"). The values are in correspondence with that of the normal range for healthy birds as stated by Mitruka and Rawnley (1977). Our results the observed enhancement in the performance traits may be due to the effects of the most important activities of essential plant oils which cause improvement in the endogenous enzymes secretion and stimulation of appetite, digestibility and nutrients absorption, improvement of the microflora balance and the decrease of E.coli and Clostiridium population and stimulating of the Lactobacillus spp . Proliferation, were also involved in the advantage of these oils. Intestinal villi layer production, antibacterial, antiviral and anti-diarrhea activity and stimulation of the immune system were also enhanced (Horobowicz, 2000).

There were significant increases in the concentration of serum total protein in groups fed diet supplemented with 0.5, 1 and 2\% Spearmint compared to the control group (Table 3). As a percentage compared to the control group the increases were $0.56 \%, 8.5 \%$ and $14.6 \%$ in group $0.5,1$ and $2 \%$, respectively. The chickens fed diet supplemented with of $2 \%$ Spearmint was lower significantly in the serum total cholesterol compared with the control group and other groups, while, there was no significant difference between the control group and $0.5 \%$ and $1 \%$ Spearmint. Chickens fed diet supplemented with 1\% Spearmint had higher significantly concentration of serum total lipid, while there were no significantly differences between the control group and $0.5 \%$ \& $2 \%$ Spearmint. The concentration of serum total triglyceride and plasma total glucose were not significantly affected with the different levels of Spearmint. There was significantly high SOD activity on group treated with 2\% Spearmint. Meanwhile, the chicken supplemented with $1 \%$ Spearmint had higher significantly TAC compared with the control group and the other treated groups. Khursheed et al. (2017) mentioned that a variety of essential oil compounds, such as menthone, menthol and geraniol have been shown to suppress the hepatic 3hydroxy-3-methylglutaryl coenzyme A (HMG-CoA) reductase activity. In the present study, the no significant effect on serum cholesterol level may be related to relatively low doses of mint which might have implicated in the failure of mint to reduce plasma cholesterol levels Aghazadeh et al., (2011) reported that total cholesterol concentrations were significantly reduced by Mint extract treatments compared to the control group at 21 and $42 \mathrm{~d}$ of age. The hypocholestrolaemic effect of Mint has been attributed to inhibition of HMGCoA reductase (Elson and Qureshi, 
Aida A. Abu Isha ${ }^{1}$ et al.

1995), the rate-controlling enzyme of cholesterol synthetic pathway.

Sharifi et al., (2013) mentioned that the addition peppermint $(3 \mathrm{~g} / \mathrm{kg}$ diet $)$ increased the concentration of triglyceride compared to the control. This may be due to a reduction in the growth and activity of the intestinal microflora responsible for bile salt catabolism. Therefore, by reducing the intestinal bacteria populations, peppermint also lowered the deconjugation of bile salts that led to reduced impairment of fat emulsification and lipid absorption (Guban et al., 2006), hence resulting in triglyceride and total cholesterol increments. Elamin et al., (2015) studied the serum metabolite value of broiler chicks fed different levels of spearmint for 6 weeks. Mean values of cholesterol were higher significantly $(\mathrm{P}<0.05)$ in negative and positive control group compared to $1,1.5,2 \%$ spearmint (Mentha spicata) groups, no significant difference is seen between $1,1.5,2 \%$ spearmint. However cholesterol decreased as the level of dietary spearmint increased. Treatments effect on total protein, urea and glucose were not significant ( $p>0.05)$, Enzyme activities of broiler chicks fed different level of spearmint for 6 weeks. AST values were significantly $(\mathrm{p}<0.05)$ high in negative and positive control group compared to other groups, whereas no significant difference is found between $1,1.5$ and $2 \%$ spearmint. The result of serum metabolites showed that cholesterol values were significantly lower in groups of chicks fed spearmint. This could be explained as spearmint containing menthol and menthone and these active ingredients may inhibit the activity of HMG-Co A reductase (Crowell, 1999; Eleson, et al. 1989). This enzyme is a key regulatory in cholesterol enzyme synthesis. In addition the reduction in blood cholesterol could be attributed fatty acids including cholesterol and triglyceride(Ami-Azghadi et al., 2010; and Kajeali et al., 2012).

Elamin et al., (2015) showed that no significant differences between the treatments (positive and negative control, $1,1.5,2 \%$ spearmint) in serum total protein and glucose being similar. This agreed with, Fallah et al., (2013) who stated that the serum total protein and glucose of broiler did not affect significantly by the addition of Mentha (Mentha pipperita) extract in at level $200 \mathrm{mg} / \mathrm{kg}$ in drinking water .Similarly, Amal (2012) found that the addition of spearmint essential oils to broiler diets caused non- significant effect on serum total protein of broiler.

There were no significant effect of the supplementation of different levels of Spearmint in chicken's diets on Carcass weight percentage, Gizzard, Liver, Heart, Edible parts and Carcass yield (Table 4). Meanwhile, the abdominal fat percent did not significantly affect by addition of Spearmint on chickens diets compared to the control group. Chickens in a group fed diet supplemented with $0.5,1$ and $2 \%$ Spearmint increased numerally the percentage abdominal fat compared with control group.

There were no significant differences between the control group and the groups supplemented with $0.5,1$ and $2 \%$ Spearmint on the pancreas weight percentage, and the intestine length (Table 5), while, chickens fed diet supplemented with 0.5 and $1 \%$ Spearmint had lower percentage weight proventriculus and intestine weight compared with the control group and the group treated with $2 \%$ Spearmint. 
Similarly, Cetingul et al. (2016) stated that no significant difference was observed among the groups in carcass, liver, heart weights. Although the increase in liver weights of groups $4 \%$ and 5\% Peppermint was dramatic, it was determined to have no statistical significance. The increased liver weights could be due to the dilatation of liver veins as previously reported (Akdogan et al., 2004).

No significant influence of dry peppermint supplement on the relative weights of the whole gut, pancreas and edible inner organs, at slaughter age in broilers. (Toghyani et al., 2010 and Ocak et al., 2008).

On the other hand, Elamin et al., (2015) studied the effect of addition spearmint in the diet on the abdominal fat percentage. They found that spearmint inclusion significantly $(\mathrm{P}>0.05)$ lowered abdominal fat percentage for broiler chicks fed on this natural feed additives at all level of inclusion as opposite to those of negative control and antibiotic (positive control) group which recorded the highest abdominal fat percentage. The reduction of abdominal fat for the diets that supplement with these natural feed additives may attribute to possess lipids lowering effects (Kawda et al., 1988). However, the mechanism of reducing abdominal fat by herbs feed additive may be through increasing the secretion of lipase and secondary bile acids. As the result, lower amounts of fatty acids are accumulating in abdominal cavity because of high lipid metabolism due to lipase secretion. (Najafi and Taherpour, 2014).

\section{CONCLUSION}

supplementation of different spearmint levels $(0.5,1$ and $2 \%)$ in broiler diet had significantly improved their productive performance and decreased the total lipid profile. Meanwhile, supplementation of spearmint at $1 \%$ level in broiler diets could significantly improve the total antioxidant capacity in blood. 
Aida A. Abu Isha ${ }^{1}$ et al.

Table (1): Effect of spearmint ( Mentha spicata ) on growth performance of broiler chicks at 42 days of age $\left(\mathrm{X}^{-} \pm \mathrm{SE}\right)$

\begin{tabular}{|l|c|c|c|c|c|}
\hline Treat. & $\begin{array}{c}\text { Initial B.W } \\
\text { "g" }\end{array}$ & $\begin{array}{c}\text { Final B.W } \\
\text { "g" }\end{array}$ & $\begin{array}{c}\text { B.W.G "g" } \\
\mathbf{( 7 - 4 2 ~ d ) ~}\end{array}$ & $\begin{array}{c}\text { Feed } \\
\text { consumption } \\
\text { 'g/chicken" }\end{array}$ & F.C.R \\
\hline T1 & $148.33 \pm 4.10$ & $2015.61^{\mathrm{a}} \pm 18.6$ & $1867.28^{\mathrm{a}} \pm 29.0$ & $3016^{\mathrm{a}} \pm 1.09$ & $1.62^{\mathrm{a}} \pm 0.03$ \\
T2 & $145.22 \pm 3.40$ & $1995.56^{\mathrm{a}} \pm 32.8$ & $1850.33^{\mathrm{a}} \pm 35.8$ & $2942^{\mathrm{b}} \pm 0.88$ & $1.59^{\mathrm{b}} \pm 0.02$ \\
T3 & $150.67 \pm 2.44$ & $1952.33^{\mathrm{a}} \pm 36.2$ & $1801.67^{\mathrm{a}} \pm 37.9$ & $2807^{\mathrm{c}} \pm 1.92$ & $1.56^{\mathrm{b}} \pm 0.02$ \\
T4 & $147.58 \pm 6.59$ & $1852.37^{\mathrm{b}} \pm 18.1$ & $1704.19^{\mathrm{b}} \pm 16.8$ & $2631^{\mathrm{d}} \pm 3.84$ & $1.54^{\mathrm{b}} \pm 0.01$ \\
P value & 0.883 & 0.012 & 0.012 & 0.0001 & 0.027 \\
\hline
\end{tabular}

T1: the control diet (without any addition), T2: O.5\% spearmint, T3: 1\% spearmint, T4: $2 \%$ spearmint - a,b: Means in each row with different superscripts are significantly different $(\mathrm{p}<0.05)$

Table (2): Effect of spearmint ( Mentha spicata ) on hematological parameters of broiler chicks at 42 days of age $\left(\mathrm{X}^{-} \pm \mathrm{SE}\right)$

\begin{tabular}{|l|c|c|c|c|c|}
\hline \multirow{2}{*}{\multicolumn{1}{c|}{ Parameters }} & \multicolumn{5}{|c|}{ Spearmint level } \\
\cline { 2 - 6 } & T1 & T2 & T3 & T4 & P value \\
\hline $\mathrm{Hb}(\mathrm{g} / 100 \mathrm{ml})$ & $10.67 \pm 0.28$ & $10.87 \pm 0.57$ & $11.07 \pm 0.09$ & $11.27 \pm 0.99$ & 0.900 \\
$\mathrm{RBC}^{*} 10^{6}\left(\mathrm{cell} / \mathrm{mm}^{3}\right)$ & $2.42 \pm 0.05$ & $2.31 \pm 0.06$ & $2.41 \pm 0.07$ & $2.58 \pm 0.18$ & 0.387 \\
$\mathrm{HT}(\%)$ & $31.00 \pm 0.57$ & $31.17 \pm 1.02$ & $32.90 \pm 0.58$ & $32.57 \pm 2.73$ & 0.752 \\
$\mathrm{MCV}\left(\right.$ micron $\left.^{3}\right)$ & $128.17 \pm 5.02$ & $135.17 \pm 1.17$ & $137.27 \pm 5.73$ & $126.13 \pm 2.72$ & 0.239 \\
$\mathrm{MCH}(\mathrm{pg})$ & $44.07 \pm 2.08$ & $46.93 \pm 1.29$ & $46.03 \pm 1.56$ & $43.50 \pm 0.93$ & 0.394 \\
$\mathrm{MCHC}(\mathrm{g} / 100 \mathrm{ml})$ & $34.33 \pm 0.41$ & $34.80 \pm 0.66$ & $33.60 \pm 0.32$ & $34.56 \pm 0.26$ & 0.311 \\
\hline
\end{tabular}

T1: the control diet (without any addition), T2: O.5\% spearmint, T3: 1\% spearmint, T4: $2 \%$ spearmint 
Table (3): Effect of spearmint ( Mentha spicata ) on biochemical constituents of broiler chicks at 42 days of age ( $\left.\mathrm{X}^{-} \pm \mathrm{SE}\right)$

\begin{tabular}{|c|c|c|c|c|c|}
\hline \multirow{2}{*}{ Parameters } & \multicolumn{5}{|c|}{ Spearmint level } \\
\hline & T1 & $\mathbf{T} 2$ & T3 & T4 & P value \\
\hline Glucose(mgldl) & $203.67 \pm 10.14$ & $182.33 \pm 19.84$ & $211.67 \pm 19.72$ & $184.33 \pm 10.17$ & 0.539 \\
\hline Total protein $(\mathrm{g} \backslash 100 \mathrm{ml})$ & $3.04^{b} \pm 0.14$ & $3.06^{\mathrm{b}} \pm 0.17$ & $3.30^{\mathrm{ab}} \pm 0.09$ & $3.49^{\mathrm{a}} \pm 0.02$ & 0.042 \\
\hline Albumin (g\100ml) & $1.573 \pm 0.19$ & $1.570 \pm 0.05$ & $1.660 \pm 0.04$ & $1.790 \pm 0.13$ & 0.576 \\
\hline Globulin (g\100ml) & $1.470 \pm 0.12$ & $1.490 \pm 0.13$ & $1.643 \pm 0.11$ & $1.696 \pm 0.11$ & 0.320 \\
\hline Total Lipids (mgldl) & $365.00^{\mathrm{b}} \pm 16.92$ & $354.00^{\mathrm{b}} \pm 27.22$ & $496.60^{\mathrm{a}} \pm 39.59$ & $297.33^{\mathrm{b}} \pm 30.90$ & 0.001 \\
\hline Total Cholesterol (mgldl) & $81.33^{\mathrm{a}} \pm 3.93$ & $81.00^{\mathrm{a}} \pm 3.21$ & $79.00^{\mathrm{a}} \pm 4.58$ & $55.80^{\mathrm{b}} \pm 3.76$ & 0.001 \\
\hline Triglyceride (mgldl) & $70.33 \pm 1.67$ & $52.00 \pm 7.00$ & $62.50 \pm 6.06$ & $69.80 \pm 6.77$ & 0.236 \\
\hline $\operatorname{SOD}(\mathrm{u} / \mathrm{dl})$ & $1.56^{\mathrm{b}} \pm 0.16$ & $2.77^{\mathrm{ab}} \pm 0.34$ & $2.43^{\mathrm{ab}} \pm 0.78$ & $3.95^{\mathrm{a}} \pm 0.17$ & 0.030 \\
\hline TAC (mMol/dl) & $1.73^{\mathrm{b}} \pm 0.15$ & $1.52^{\mathrm{bc}} \pm 0.04$ & $2.37^{\mathrm{a}} \pm 0.33$ & $1.13^{c} \pm 0.09$ & 0.010 \\
\hline
\end{tabular}

T1: the control diet (without any addition), T2: O.5\% spearmint, T3: 1\% spearmint, T4: $2 \%$ spearmint - a,b: Means in each row with different superscripts are significantly different $(\mathrm{p}<0.05)$ 
Aida A. Abu Isha ${ }^{1}$ et al.

Table (4): Effect of spearmint ( Mentha spicata ) on carcass traits of broiler chicks at 42 days of age $\left(\mathrm{X}^{-} \pm \mathrm{SE}\right)$

\begin{tabular}{|l|c|c|c|c|c|}
\hline \multirow{2}{*}{\multicolumn{1}{|c|}{ Parameters }} & \multicolumn{5}{c|}{ Spearmint level } \\
\cline { 2 - 6 } & T1 & T2 & T3 & T4 & P value \\
\hline Carcass (g\%) & $69.51 \pm 1.39$ & $70.49 \pm 0.96$ & $70.12 \pm 0.55$ & $68.16 \pm 0.88$ & 0.257 \\
Gizzard (g\%) & $1.41 \pm 0.13$ & $1.15 \pm 0.08$ & $1.29 \pm 0.14$ & $1.39 \pm 0.24$ & 0.686 \\
Liver (g\%) & $2.69 \pm 0.25$ & $2.41 \pm 0.07$ & $2.84 \pm 0.31$ & $2.50 \pm 0.11$ & 0.597 \\
Heart (g\%) & $0.41 \pm 0.04$ & $0.52 \pm 0.06$ & $0.47 \pm 0.03$ & $0.53 \pm 0.02$ & 0.355 \\
Edible parts(g\%) & $4.51 \pm 0.32$ & $4.08 \pm 0.09$ & $4.61 \pm 0.36$ & $4.41 \pm 0.32$ & 0.628 \\
Carcass yield(g\%) & $74.02 \pm 1.61$ & $74.58 \pm 1.06$ & $74.73 \pm 0.48$ & $72.57 \pm 0.57$ & 0.478 \\
Abdominal fat (g\%) & $0.88 \pm 0.48$ & $0.97 \pm 0.16$ & $1.41 \pm 0.07$ & $1.15 \pm 0.13$ & 0.508 \\
\hline
\end{tabular}

T1: the control diet (without any addition), T2: O.5\% spearmint, T3: 1\% spearmint, T4: $2 \%$ spearmint

Table (5): Effect of spearmint ( Mentha spicata ) on non-edible parts of broiler chicks at 42 days of age $\left(\mathrm{X}^{-} \pm \mathrm{SE}\right)$

\begin{tabular}{|l|c|c|c|c|c|}
\hline \multirow{2}{*}{\multicolumn{1}{c|}{ Parameters }} & \multicolumn{5}{|c|}{ Spearmint level } \\
\cline { 2 - 6 } & \multirow{2}{*}{ T1 } & T2 & T3 & T4 & $\begin{array}{c}\text { P } \\
\text { value }\end{array}$ \\
\hline Pancreas (g\%) & $0.28 \pm 0.05$ & $0.27 \pm 0.05$ & $0.28 \pm 0.03$ & $0.31 \pm 0.04$ & 0.932 \\
Proventriculus(g\%) & $0.55^{\mathrm{ab}_{\mathrm{b}} \pm 0.02}$ & $0.34^{\mathrm{c}} \pm 0.09$ & $0.44^{\mathrm{bc}} \pm 0.01$ & $0.59^{\mathrm{a}} \pm 0.01$ & 0.018 \\
Intestine weight $(\mathrm{g} \%)$ & $5.10^{\mathrm{ab}^{\mathrm{b}} \pm 0.38}$ & $3.70^{\mathrm{b}} \pm 0.99$ & $4.08^{\mathrm{b}} \pm 0.42$ & $6.50^{\mathrm{a}} \pm 0.60$ & 0.050 \\
Intestine length"cm" & $184.33 \pm 19.09$ & $153.67 \pm 15.89$ & $179.33 \pm 11.26$ & $205.00 \pm 15.82$ & 0.285 \\
\hline
\end{tabular}

T1: the control diet (without any addition), T2: O.5\% spearmint, T3: 1\% spearmint, T4: $2 \%$ spearmint - a,b: Means in each row with different superscripts are significantly different $(\mathrm{p}<0.05)$ 


\section{REFERENCES}

Aami-Azghadi, M.; Golian, A.; Kermanshahi, H.; and Sedghi, M., 2010. Comparison of dietary supplementation with cumin essential oil and prebiotic fermacto on humoral immune response, blood metabolites and performance of broiler chickens. Global Veterinaria, 4: 380-387.

Aghazadeh, A. M.; Abdolkarimi, R.; and Ashkavand, Z., 2011. Effect of Dietary Thyme (Thymus vulgaris) and Mint (Menthe piperita) on Some Blood Parameters of Broiler Chickens. Journal of Agricultural Science and Technology A 1, 1288-1290.

Akdogan, M.; Ozguner, M.; Aydýn, G.; and Gokalp, O., 2004. Investigation of biochemical and histopathological effects of Mentha piperita Labiatae and Mentha spicata Labiatae on liver tissue in rats. Human and Experimental Toxicology, 23: 21-28.

Al-Kassie, G. A. M., 2010. The Role Of Peppermint (Mentha Piperita) On Performance In Broiler Diets. Agric. Biol. J. N. Am., 1(5): 1009-1013.

Allain, C. A.; Poon, L. S.; Chang, C. S. G.; Richmond, W.; and Fu P. C., 1974. Enzymatic determination of total serum cholesterol. Clin. Chem., 20:470-475.

Amal, O. A. A., 2012. Use of oils in broiler Nutrition- thesis submitted in Accordance with the requirements of the Sudan University of Science and Technology for the degree of Doctor Philosophy.

Bampidis, V. A.; Christodoulou, V.; Florou -Paneri, P.; Christaki, E.; Chatopoulou, P. S.; Tsiligianni, T.; and Spais, A. B., 2005. Effect of dietary dried oregano leaves on growth performance, carcass characteristics and serum cholesterol of female early maturing turkeys. Brit. Poult.Sci., 46, 595- 601.

Banerjee, G. C., 1998. A Text Book of animal Husbandry.2nd edition Indic Publication, Delhi, India

Beauchamp, C.; and Fridovich, I., 1971. Superoxide dismutase: improved assays and an assay applicable to acrylamide gels. Anal. Biochem; 44: 276-287.

Bogen, E.; and kaller, P., 1987. Application of chemical biochemistry to medically relevant animal models and standardization and quality control in animal biochemistry. $\mathrm{J}$. Clin. Chem. Clin. Biochem. 25:873878.

Bushra, H. A., 2011. Effect of Dietary Levels of Spearmint (Mentha spicata) on Broiler Chicks Performance .M. SC. Thesis (in animal production). Department of Animal Nutrition, Faculty of Animal Production University of Khartoum, Sudan. Cetingul, I. S.; Bayram, I.; Kucukkurt, I.; Akkaya, A. B.; Uyarlar, C.; Yardimci, M.; Gultepe, E. E.; and Rahman, A., 2016. Effect of peppermint (Mentha piperita) supplementation on carcass yield, meat taste, heart weight, liver weight and some blood parameters in laying quail (Coturnix Coturnix Japonica). Indian J. Anim. Res., 50 (4) : 512-517. Chabrol, E.; and Charonnat, R., 1973. Determination of total lipids. Press Med., 45: 1713-1720. Doumas, B. T.; Bayse, D. D.; Carter, R. J.; Peters, T. Jr.; and Schaffer, R., 1981. Acandidate reference method for determination of total protein in serum. Clin. Chem., 271:1642-1650.

Doumas, B. T.; Watson, W. A.; and Biggs, H. G., 1971. Albumin 
Aida A. Abu Isha ${ }^{1}$ et al.

standards and the measurement of serum albumin with bromocresol green. Clin. Chem. Acta, 31: 87-96.

Cross, D. E.; McDevitt, R. M .; Hillman, K.; and Acamovic, T., 2007. The effect of herbs and their associated essential oils on performance, dietary digestibility and gut microflora in chickens from 7 to 28 days of age .Brit. Poult. Sci., 48, 496-506.

Crowell, P. L., 1999. Prevention and therapy of cancer by dietary monoterpenes. J. Nut., 129: 775-778.

Durrani, F. R.; Sultan, A.; Marri, M. L.; Chand, N.; and Durrani, Z., 2007. Effect of wild mint (Mentha longifolia) infusion on the overall performance of broiler chicks. Pak. J. Biol. Sci., 10:1130 - 1133.

Eleson, C. E.; Underbakke, G. I.; Hanson, P.; Shrago, E.; Wainbeng, R. H.; and Qureshi, A. A., 1989. Impact of lemograss oil an essential oil on serum cholesterol lipids, 24: 677-679.

Eleson, C. E.; and Qureshi, A. A., 1995. Coupling the cholesterol and tumorsuppressive actions of palm oil to impact of its minor constituents on 3hydroxy-3-methylglutsryl coenzyme A reductase activities, Prostaglandins Leukotrients and Essential Fatty Acids 52 205-208.

Fallah, R.; Kianim, A.; and Azarfar, A., 2013. Effect of artichoke leaves meal and mentha extract (Mentha pipreita) on immune cells and blood biochemical parameters of broilers. Global Veterinaria 10 (1): 99-102, 2013ISSN 19926197@ IDOSI Publications, $2013 \quad$ DOI: 10.5829/idosi.gv.2013.10.1.71206

Galib, M.; Al-kassi, M. W.; and Noor, A., 2010. A comparative study on diet supplementation with a mixture of herbal plants and dandelion as a source of probiotics on the performance of broilers. Pakistan. J Nutrition, 9(1): 67-71.

Guban, J.; Korver, D. R.; Allison, G. E.; and Tannock, G. W., 2006. Relationship of dietary antimicrobial drug administration with broiler performance, decreased population levels of Lactobacillus salivarius, and reduced bile salt deconjugation in the ileum of broiler chickens. Poult. Sci. 85, 2186-2194.

Hawkeye, C. M.; and Dennett, T. B., 1989. A Color Atlas of Comparative Veterinary Hematology Wolf. Publishing Limited, London, England.

Horbowicz, M., 2000. Wystpowanie, biosynteza, Wlaoeciwoeci biochemiczne flawonoli .Post. Nauk Rol., 2: 3-1.

Howida, A. Y., 2009. Influence of Dietary Spearmint (Mentha spicata) Supplementation on Broiler Chicks Performance. M. SC. Thesis (In Nutritional Science), Dep. Anim. Nutri., Faculty of Animal Production, University of Khartoum, Sudan.

Huda, M. S. Elamin; Mohamed, K. A.; and Mukhtar, M. A., 2015. Effect of Spearmint (Mentha spicata) on performance and blood serum parameter of broiler. Journal of Social Sciences Research. 8, No. 2

Hussain, A. I.; Anwar, F.; Nigam, P. S.; Ashraf, M.; and Gilani, A. H., 2010. Seasonal variation in content, chemical composition and antimicrobial and cytotoxic activities of essential oils from four Mentha species. Journal of the Science of Food and Agriculture 90(11): 1827-1836.

Hyvarinen, A.; and Nikkila, E. A., 1962. Determination of blood glucose 
with O. Toludine. Nut. Abst. Rev., 32:589.

Jafari, B.; Kamerani, M.; and Rezazadehreyhani, Z., 2011. Influence of different level of Spearmint(Mentha spicata) extract on different parameters of Laying Hens Annals of Biological Research, 2 (6):517-521.

Kawada, T.; Sakabe, S.; Watanbe, T.; Yamamoto, M.; and Iwai, K., 1988. some pungent principle of spices caused the adrenal medulla to secret catecholamine in one shetize rate proc. Soc. Exp. Boil. Med. 188-229-233.

Khajeali, Y.; Kheiri, F.; Rahimian, Y.; Faghani, M.; and Namjo, A., 2012. Effect of use different levels of Caraway (Carum carvi L.) powder on performance, some blood parameters and intestinal morphology on broiler chickens. World Applied Sciences Journal,19: 1202-1207.

Khursheed, A.; BAndAy, M. T.; KhAn, A. A.; Adil, S.; GAnAi, A. M.; sheikh, I. U.; and sofi, A. H., 2017. Effect of mint leaves with or without enzyme supplementation on blood biochemistry, carcass characteristics and sensory attributes of broiler chicken. Adv. Anim. Vet. Sci. 5(11): 449-455.

Koracevic, D.; Koracevic, G.; Djordjevic, V.; Andrejevic, S.; and Covic, V., 2001. Method for the measurement of antioxidant activity in human fluids. J. Clin. Path.; 54:356361.

Lilja, C., 1983. Compartive study of postnatal growth and organ development in some species of birds. Growth, 47, 317 - 329.

Lovkova, M. Y.; Buzuk, G. N.; Sokolova, S. M.; and Klimenteva, N. I., 2001. Chemical of medicinal plants (a review ) . Appl. Biochem . Microbiol ., 37, 229-237.

Lucky, Z., 1977. Methods for The Diagnosis of Fish Diseases. Ameruno Publishing Co., PVT, LTD. New Delhi, Bomby, New Yourk.

Mitruka, B. M.; and Rawnsly, H. M., 1977. Clinical Boichemical and Hematological Reference Values in Normal Experimental Animals. J. Clin. Pathol.; 32(1):96.

Mukhtar, M. A.; Mohamed, K. A.; Amal, O. A.; Ahlam, A. H., 2013. Response of broiler chicks to different dietary levels of spearmint oil (SPO) as a natural growth promoter. University of Bakht Alruda Scienfic Journal Issue No.6.

Najafi, S.; and Taherpour, K., 2014. Effects of dietary ginger (Zingiber ofjicinale), cinnamon (Cinnamomum), synbiotic and antibiotic supplementation on performance of broilers. J. Anim. Sci. Adv., 4(1): 658667.

National Research Council (NRC), 1994. Nutrient Requirements of Poultry. 9th Edn. National Academy Press, Washington, DC. of Alletchs 10th Annual Symposium. Nottingham University Press, Nottingham, UK.

Ocak, N.; Erener, G.; Burak, Ak F.; Sungu, M.; Altop, A.; and Ozmen, A., 2008. Performance of broilers fed diets supplemented with dry peppermint (Mentha piperita L.) or thyme (Thymus vulgaris L.) leaves as growth promoter source. Czech J. Anim. Sci., 53, (4): 169-175.

SAS Institute, 2002. SAS/STAT User's guide statistics. SAS institute INC., Cary. NC, USA.

Sharifi, S. D.; Khorsandi, S. H.; Khadem, A. A.; Salehi, A.; and Moslehi, H., 2013. The effect of four medicinal plants on the performance, blood biochemical traits and ileal 
Aida A. Abu Isha ${ }^{1}$ et al.

microflora of broiler chicks. Veterinarski. Arhiv, 83 (1): 69-80.

Singh, C. S.; and Agarwal, R., 2013. Evaluation of antibacterial activity of volatile oil from Mentha spicata L. Journal of Drug Delivery and Therapeutics 3(4): 120-121. Tietz, N. W., 1982. Fundamental of Clinical Chemistry. Edition by Nobert Sounder Comp., Philadelphia, USA.

Toghyani, M.; Majid, M.; Abbasali, Gh.; Gholamreza, Gh.; and Mohammad, M., 2010. Growth performance, serum biochemistry and blood hematology of broiler chicks fed different levels of black seed (Nigella sativa) and peppermint (Mentha piperita). Livestock Science, 129: 173-178.

Wintrobe, P. M., 1965. Clinical Hematology. Lead and Febiger Philadelphia, USA.

Yoshimura, H.; Ishimaru, M.; Endoh, Y. S.; and Kojima, A., 2000. Antimicrobial susceptibilities of enterococci isolated from faeces of broiler and layer chickens. Lett. Appl. Microbial. 31:427-432.

Zaidi, S.; and Dahiya, P., 2015. In vitro antimicrobial activity, phytochemical analysis and total phenolic content of essential oil from Mentha spicata and Mentha piperita. International Food Research Journal 22(6): 2440-2445. 


$$
\text { الملخص العربى }
$$

\section{تأثير إضافة النعناع على الأداء الإنتاجي والفسيولوجي لكتاكيت اللحم}

عايدة عبد المجيد أبو عيثة1، عبد الحميد السيد عبد الحميد1، حامد مرسى زينة2، حمادة عبد العزيز السيد أحمد3

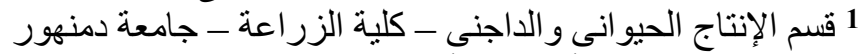

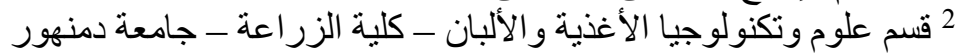

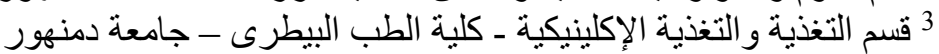

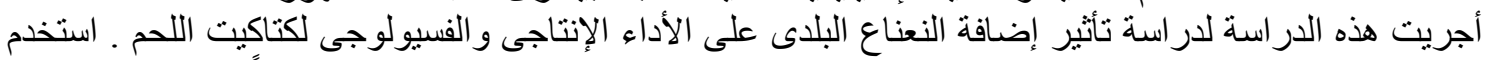

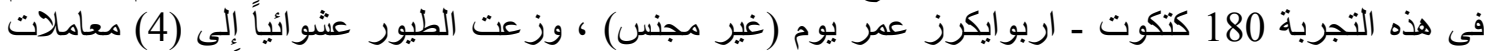

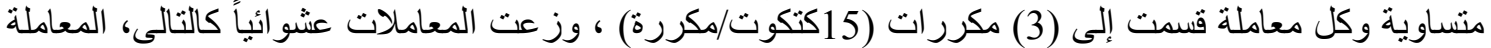

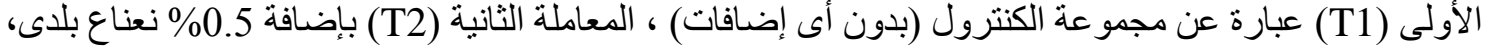

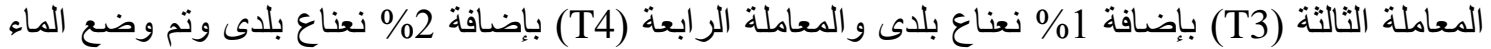

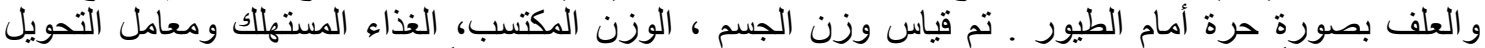

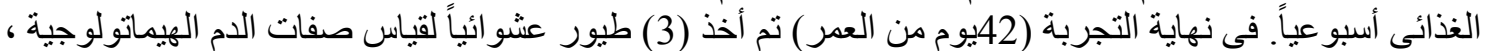
البيوكيميائية وصفات الذبيحة النيحة

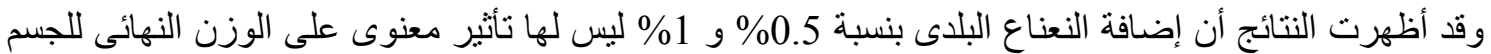

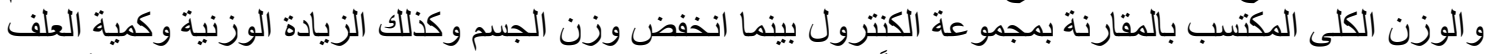

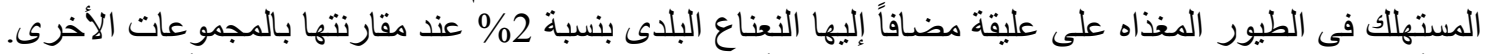

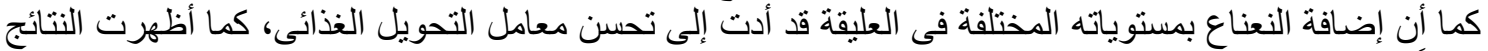

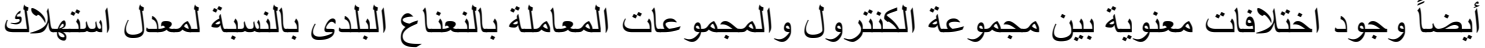

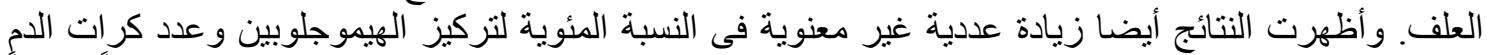

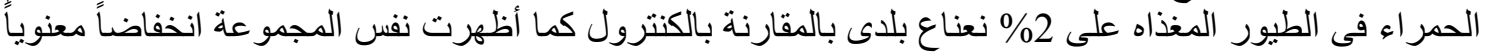

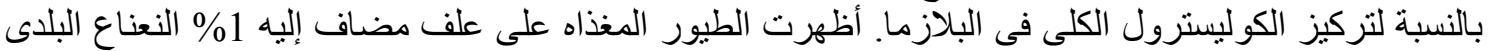

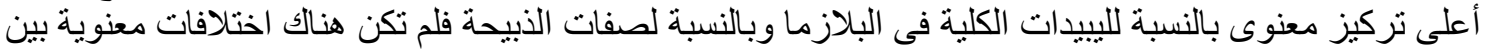

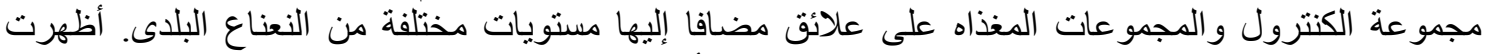

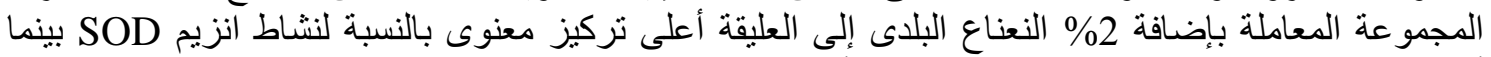

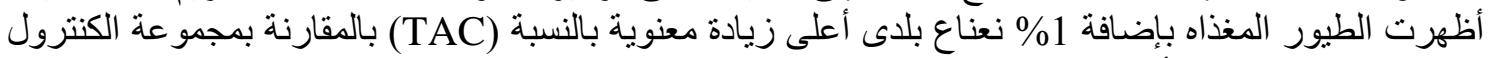

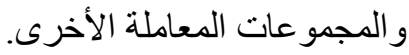

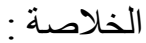

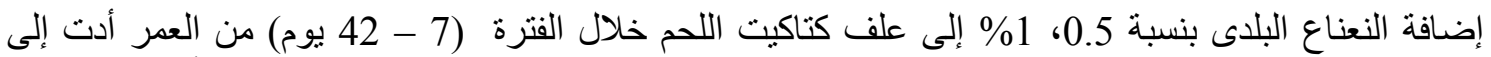

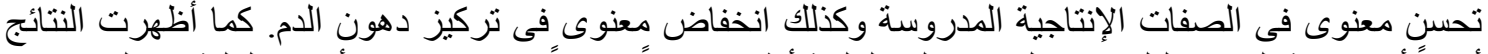

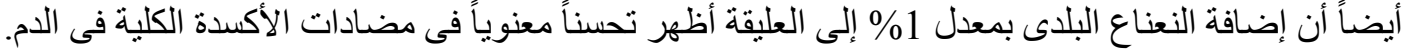

